\begin{tabular}{|c|c|}
\hline ANGLES & Angles \\
\hline $\begin{array}{l}\text { NEW PERSPEETWUES } \\
\text { ANELOPHONE WORLD }\end{array}$ & New Perspectives on the Anglophone World \\
\hline & $\begin{array}{l}7 \mid 2018 \\
\text { Digital Subjectivities }\end{array}$ \\
\hline
\end{tabular}

\title{
Max Aguilera-Hellweg, Photography from surgery to robotics
}

Jessica Ragazzini

Translator. Claire Larsonneur and Madelena Gonzalez

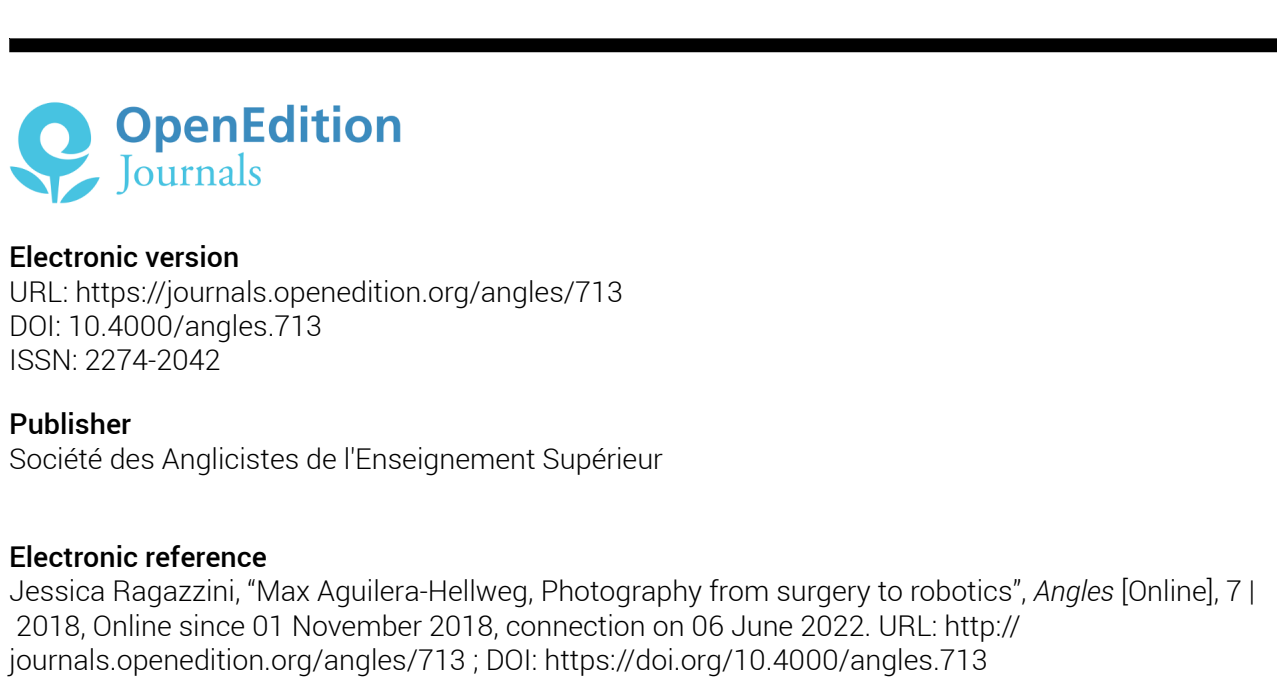

This text was automatically generated on 6 June 2022.

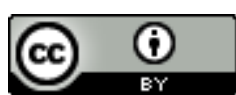

Angles est mise à disposition selon les termes de la Licence Creative Commons Attribution 4.0 International. 


\title{
Max Aguilera-Hellweg, Photography from surgery to robotics
}

\author{
Jessica Ragazzini
}

Translation : Claire Larsonneur and Madelena Gonzalez

1 Anthropomorphic robots have become increasingly important in contemporary society as shown by the recent adoption of "Civil law rules on robotics" by the European Parliament on February 16, 2017 calling for a definition of smart robots based on: the acquisition of autonomy through sensors and/or by exchanging data with its environment (inter-connectivity) and the trading and analysing of those data; selflearning from experience and by interaction (optional criterion); at least a minor physical support, the adaptation of its behaviour and actions to the environment; absence of life in the biological sense.

2 This conflation of living beings and inert artefacts is not new, especially in art. For centuries, artistic productions have staged objects as if they were living beings; today an increasing number of artists are abandoning living models in favour of their simulacra. As American photographer Max Aguilera-Hellweg shifted his work focus from surgery to robotics, he challenged and questioned the photographic relationship between body and object.

3 The artistic conflation of what is living and what is inert can already be spotted in Ancient Greek literature and myth, through the emblematic cases of Pygmalion, Zeuxis and Parrhasios. These three creators represent the power of art to impart life to artefacts, either with the help of the gods or by dint of their sole talent. This power stimulated the artistic imagination throughout the centuries and many artists explored the borders between living humans and anthropomorphic artefacts, sometimes even entirely focusing on the latter. Why this shift? What do anthropomorphic artefacts offer that the human body does not have? Is there a hierarchy between them? And in the case of Max Aguilera-Hellweg, what do photographic techniques bring to the debate? The exhibition Mannequin d'artiste mannequin fétiche which took place in 2015 at the Museum Bourdelle in Paris focused on one type of anthropomorphic artefact that was first designed for technical and utilitarian purposes: simulating a human face to 
understand it better. The perfect stillness of the mannequin allowed painters and couturiers to create clothes that would fit human morphology and the medical mannequins were and still are used to learn how to handle human organs. The mannequin only gained the status of a subject (or was staged as such) at the onset of the $20^{\text {th }}$ century with the advent of surrealism. Similarly, photography that began as a scientific and technical tool only became an artistic medium later on.

Photography, which is of its nature a pretence of reality, offers new possibilities concerning the conflation between body and object. The 2016 Persona: étrangement humain exhibition at the Museum of the Quai Branly staged various artefacts from which emanated a feeling of life, quite like Max Aguilera-Hellweg's photographs of robots. The Persona exhibition drew upon the analyses of Freud and Jentsch: it referred to the notion of the uncanny, the particular impression of being faced with something both familiar and strange when we consider life-mimicking artefacts despite our rational knowledge that they are inanimate. The notion was inspired by the psychiatric case of a young man, Nathanael, who fell hopelessly in love with an automaton to the point of madness. First described by Hoffmann Sandermann (Hoffmann 1815), it inspired Freud (1971) and Jentsch (1998: 37-48) who coined the term "Das Unheimliche", translated as the Uncanny. The disturbing effect of the artefact, usually identified as harboring a secret, something hidden we need protection from, may lead to repressed feelings, anxiety or even madness in extreme cases such as Nathanael's. More recently, these psychoanalytical theories were revisited by the Japanese robotician Masahiro Mori in his article "Uncanny Valley" (Mori 2012). He examines the range of emotions inspired by robots or prostheses that look too much like real human beings, from interest to revulsion. Robotics questions the status of artefacts that can enter the category of the "almost living"; conversely our bodies may be apprehended as "almost artefacts". This reciprocal influence of what is living and what is inert corresponds to what Horst Bredekamp calls "Bildakts" or Image-Act, when the image seems to act on the viewer (Bredekamp 2015). Photography being itself a simulacrum, this article questions the relationships, borders and photographic links between the body and the robot through the works of Max Aguilera-Hellweg. Thus, we will begin by studying the artist's career, before investigating the aesthetic link between bodies and robots which will lead us finally to question the ambiguous nature of AguileraHellweg's photographs.

\section{Surgical photography}

Artists and performers have over the last century become increasingly interested in surgery beyond its medical relevance. In her work entitled "the reincarnation of Sainte-ORLAN" composed of nine surgical acts performed between 1990 and 1993, ORLAN opened the intimacy of the operating room to the public. A series of videos and photographs chart the different stages through which the artist freed herself from her original face and remodelled her facial identity. Remaining conscious throughout, ORLAN speaks, her eyes move; bloody gloves prick the lips of the artist who shows no signs of pain. Various objects surround the surgical act which is staged like a performance/documentary, thus differing from classical surgical rooms. Artistic surgical photography is rarer than these performances. Nevertheless, Max AguileraHellweg's approach is different, more sober. As one of the few photographers who have 
been able to capture surgical procedures, he records the traces of scalpels on anesthetized bodies (Victor-Pujebet 2015).

6 Max Aguilera-Hellweg has had an unusual career. Born in California in 1955, he started as a press photographer and became famous for his celebrity portraits. After a commission, he decided to train as a surgeon at the age of 39, pursued this career but then returned to photography. His perfect knowledge of the human body is perceptible in his works. No longer interested in the apparent surface of the body, he is fascinated by what is actually inside (Aguilera-Hellweg 2006). Going deeper than what surgery allows "he tries to photograph the soul" (Victor-Pujebet 2014, 3'15")". This new line of work is represented by his landmark book: Sacred Heart: An Atlas of the Body Seen Through Invasive Surgery (1997).

Figure 1: Brain surgery. Max Aguilera-Hellweg, The sacred heart, an atlas of the body series, 1997.

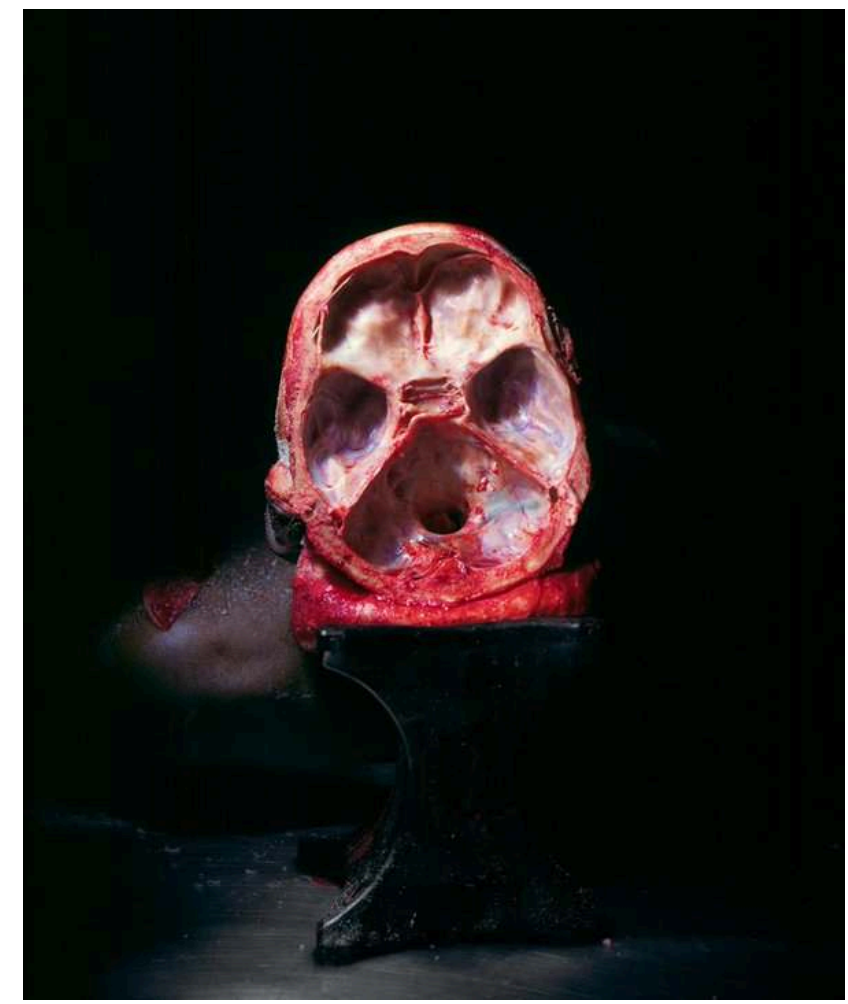

Source: https://aguilerahellweg.com/the-sacred-heart-an-atlas-to-the-body-seen-through-invasivesurgery/jjfdg8zligvhgnOrtxyydtle0dwza9. All rights reserved. 
Figure 2: Brain surgery. Max Aguilera-Hellweg, The sacred heart, an atlas of the body series, 1997.

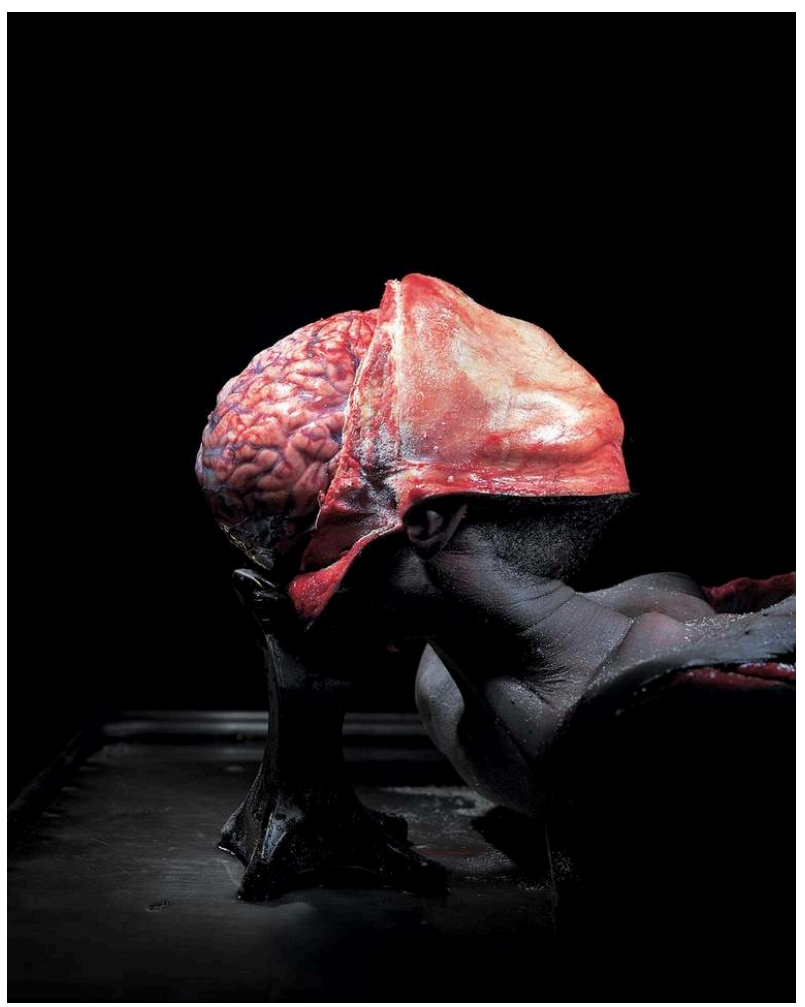

Source: https://aguilerahellweg.com/the-sacred-heart-an-atlas-to-the-body-seen-through-invasivesurgery/jjfdg8zligvhgnOrtxyydtle0dwza9. All rights reserved.

7 The viewing angles he chooses in his photographs of brain surgery (Ill. 1 and 2) reveal the inside of the skull, the removed organ. His rendition of anatomy is almost abstract: we see a simple imperfect and rounded shape, divided into several cavities but the human being has almost disappeared. The originality and aseptic quality of those photographs are the signature of the work of Aguilera-Hellweg, who chooses to leave in the dark what does not interest him. When Paul Costello asked him about the purpose of his work, he answered:

I would hope it is to accept our frailty, to accept our mortality and to appreciate life. When I was taking care of patients, most people thought they were going to live forever. Well, we don't. Hopefully, my photography demystifies the human body and makes people appreciate their lives. [...] As a photographer, I am a witness. (Costello 2017)

Since the photograph gives the impression of focusing on an anonymous object and not on a body, the viewers can distance themselves from what is actually happening. Here the recording of surgery highlights our mortal condition without showing death, by showing the transitional state of an opened anesthetized body. In his article for Savvy Magazine (1989) ${ }^{1}$, Hellweg presented a brain in its cranial box. This time, he took his photos at a wider angle with heightened luminosity, focusing solely on the body. Smooth skin contrasts with the knotty structure of the brain in a confrontation that is usually hidden. Facial hair and the dust on the torso give the impression of a rough and friable material. The chiaroscuro technique visually amputates the foreground arm and shoulder. Is this a man or an open and dismembered automaton? If Aguilera-Hellweg has always endeavoured to represent the soul of these models through his photographs (Victor-Pujebet 2014), what does he seek to show when photographing such details? 
Aguilera-Hellweg says that his objective is to photograph the soul of his models, more precisely what remains of the soul when the body is operated on. This work was rewarded by the Word Press Photo in 2000 (Aguilera-Hellweg 2006). The body is presented in a raw way, we know nothing about this brain, these skulls, this flesh they are anonymous, clean and neat. Where the photographer is present, so is the surgeon. The images of Aguilera-Hellweg are as meticulous and precise as a scalpel, as sanitized as a hospital room. The open body is presented in a luminous and detached way, and the surgical team is entirely absent: Aguilera-Hellweg's staging of the body resembles that of a sacred object.

9 Another project led to the shooting of a video "Patient No. 17" which corresponds to one of the first grafts of a bionic eye. This time, the patient is not anonymous: JoAnn Lewis recounts her experience in voiceover. However, in what follows, we will ignore her oral testimony to focus on the visual narrative presented by Max Aguilera-Hellweg. This video, produced with the support of National Geographic and now available on YouTube, isn't famous, it has only 83 views on the platform to date (Aguilera-Hellweg 2011).

This media file cannot be displayed. Please refer to the online document http:// journals.openedition.org/angles/713

Entirely filmed by hand, its quality is reminiscent of late $20^{\text {th }}$-century video art. Lighting plays an extremely important role, as in Aguilera-Hellweg's photographs. His filming and photographing techniques rely heavily on close-ups; colorimetry stays in the blues, we have a pronounced chiaroscuro and a great deal of attention to detail. The noise in these pictures evokes the grain of silver prints but Aguilera-Hellweg's videos and photographs are digitized and distributed on the Internet. We can assume that the artist articulates both silver film and digital photography, linking the two techniques to create a final work which at the same time relies on tangible material and can be dematerialized in order to be transmitted to a wider audience. The ambivalence in medium matches the ambivalence in topic: JoAnn Lewis is a hybrid being, half-woman and half-machine. Produced in 2011, could this video be the link, conscious or not, between surgical photography and robotic photography?

\section{From a fragmented body to an artificial assemblage}

Max Aguilera-Hellweg started his career as a photojournalist; in 2015, he was sensitized to the increasingly important presence of robots in our lives upon learning there were 1.6 million robots worldwide. The study of humanoids opened up a new field of investigation: "My photographs are not answers, they are questions" (Victor-Pujebet 2014, 3'53"). Now humans have always created tools and machines to help them and even replace them for various tasks. Over the last two centuries, robotics has gained ground and established itself firmly in our society. For the sake of integration and social acceptance, studies have examined the robots' appearance.

The contemporary obsession with robots and automatization more generally embodies the desire to save valuable time by delegation labour, freeing us for life's important things. The aim of these robots is thus to fulfil roles that are currently performed by people: to serve in today's service economy. It is no wonder then that these machines are configured as stereotypical human-like bodies. The future on 
offer by the evangelists of Silicon Valley, of a world replete with sociable robots, may turn out to be as radically different form the present as they claim. (Wajcman 2017: 103) soldiers' medical prostheses, which the Bush administration politicized decades later (Le Breton 2013). Artificial prostheses allow their wearers to correspond again to the standards of the human form. Faced with the fragility and precious nature of the physical envelope, the end of the century developed a cult for smooth bodies, toned and firm bodies that should remain as beautiful as possible, for as long as possible, such as those that are displayed everywhere, especially through fashion photography.

There is a growing sense that we should take control over our bodies and our social circumstances rather than just accepting what we inherited. Social and scientific trends are converging to shape a new conception of the self, a new construction of what it means to be a human being. (Deitch 1993: 27)

This new construction of the meaning of being human finds echoes in the post-human movement but also in Aguilera-Hellweg's photographic practice. Post-humanism is a philosophy that sees in the technological object the possibility of increasing and improving the human body. 
Figure 3: Max Aguilera-Hellweg, A partially assembled Joey Chaos, humanoid series, 2017.

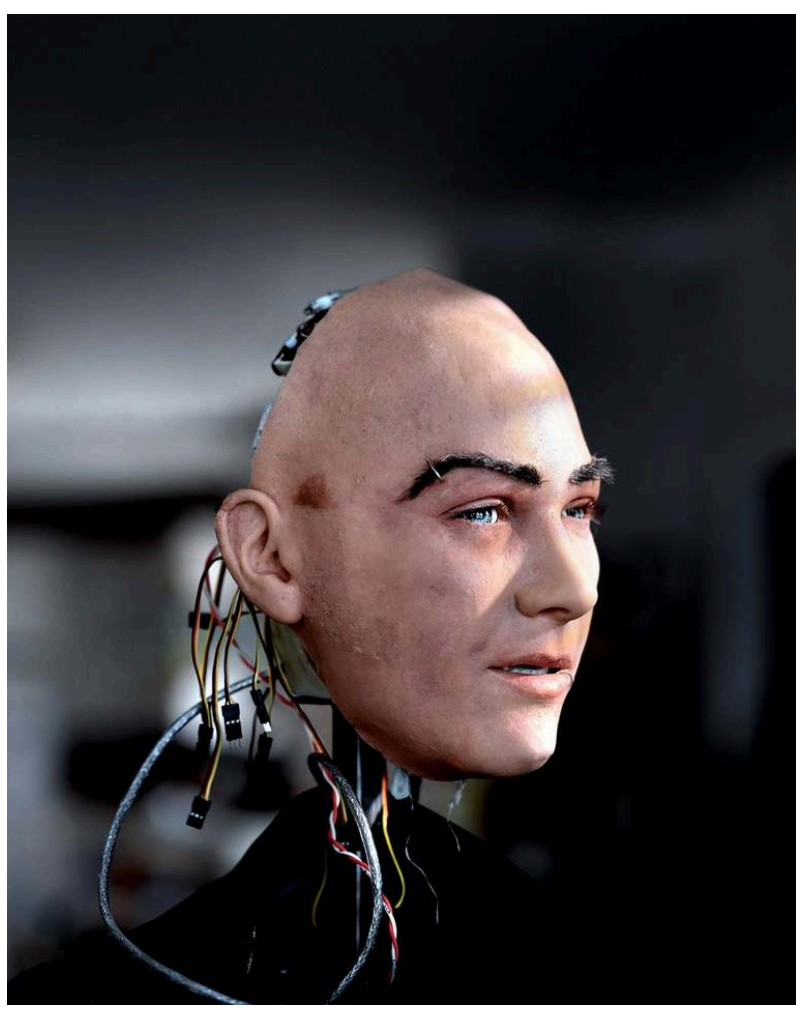

Source: https://aguilerahellweg.com/humanoid/4b0nhnr84p5biftc6v60uuhghlrula. All rights reserved.

16 If you were looking at a close-up of the face of A partially assembled Joey Chaos, it might trick you into believing you were looking at a human face. The borderline between reality and simulacrum is here very thin: the robot has skin defects, imperfect hair and wears a piercing on the brow. It is only by widening the field of vision that its robotic nature appears. The neck is reduced to metal rods and electrical wires coming out of a suit jacket. Max Aguilera-Hellweg has constructed the image of a technological scarecrow whose hair has been replaced by cables coming out of the back of the skull. Likewise, the robotic simulacrum of the roboticist Hiroshi Ishiguro is so meticulously designed that it could look like the scientist's twin. An irregular, almost porous grain of skin catches the light in contrast to the back of the smooth, sensor-covered, zippered skull. Aguilera-Hellweg's choice of lighting emphasizes the duality between robotics and humans: the overhead lamp illuminates the face, the one on ground level showcases the electric wires. Thus, Aguilera-Hellweg's production is part of an historical journey of contemporary reflections on the body and objects leading him to challenge some commonly accepted genres of photography.

\section{Photographed robots, these worrying portraits}

17 To better understand the photographic issues here, let us first ask ourselves: where is drawn the boundary between what is living and what is inert? This was the main issue explored by the 2015 Persona: étrangement humain exhibition at the Quai Branly Museum in Paris. It presented a range of artefacts that gave an impression of life. If, for a child, there is no doubt that a doll is alive and substantially similar to the human being (Mori 2012), a whole room of the exhibition was reserved for robotics. These various objects 
could come under the category of Eidolon. Eidolon is an Ancient Greek word often translated incorrectly as "image" or "idol," thereby obscuring the notions of illusion, deception and artifice that it carries originally. It is a simulacrum, a reproduction and refers to the mental image we have of an object. The Robert dictionary (Cassin 2003) and the Oxford dictionaries, as well the Dictionary of English Language (American Heritage 2016) all emphasize the element of idealization that this term possesses and add that it can also be used to designate a ghost or spectrum. In L'Effet Pygmalion, Pour une anthropologie historique des simulacres, Victor Stoichita analyses Euripides's concept of eidolon. In the passage, Helen tries to explain to Menelaus that she did not go to Troy and that Paris has lived with a fake, a statue that served as a kind of magical double and sensory illusion:

\begin{abstract}
In some places, Euripides speaks of Helen's eidolon using the word agalma, one of the most common names for the ancient Greek word for the statue. But each time he uses it, the poet adds an epithet capable of creating, but only in appearance, a contradictio in adjecto. It is the word nephelês, i. e. "made of clouds" [...] [he] introduces the theme of Helen's double statuary but skillfully brings it back to the impalpable and evanescent state. (Stoichita 2008: 136)
\end{abstract}

This artefact would give off such a living sensation (in Japanese: "Sonzai-Kan") that it could be confused with a human being. The same feeling of a living presence can be felt when viewing Max Aguilera-Hellweg's photographs. These works also evoke the schematic image-act theorized by Horst Bredekamp: in front of the photographer's lens, the object gradually becomes a body (Bredekamp 2015); an unusual body certainly, but a body with a history that the artist tries to transcribe. Like Galatea, the sculpture that comes to life in the myth of Pygmalion, the robot seems ready to move. Would the artist have the power to give life through photography? Freud already theorized the Uncanny in his analysis of Hoffmann's short story "The Sandman", where the young Nathanael falls in love with an automaton without realizing it is a simulacrum. Anthropomorphic artefacts trigger that feeling of familiarity that emanates from an unknown, and at the same time disturbing, phenomenon. In the wake of Freudian studies on the Uncanny, a roboticist's theory of the Uncanny valley was developed (Mori 2012) based on the recognition of the robot as a double of the human being. Mainly studied by roboticist Masahiro Mori (Dufrêne 2016 :167-195), the anthropomorphic robot must be sufficiently human-like to be considered with empathy. Aguilera-Hellweg plays with the ambivalence of anthropomorphism by creating photographs that sometimes give the impression that we are faced with living objects. In this way, he blurs the boundaries between traditional genres of photography, conflating a portrait (a photograph of a person) with a still life (the representation of objects). But in what category would fall photographs of artefacts shot as if they were humans and possessed a soul? If he defends his work as a photographic testimony of a revolution in our daily lives (Victor-Pujebet 2015), we cannot ignore the artist's bias: his robots are photographed with all the pathos that could be used in portraits.

On the technical side, Max Aguilera-Hellweg opted for silver prints both for his surgical and robotic projects. Silver prints convey a physical materiality that can also evoke the grain of the skin, which reinforces the parallel between robots and humans. It may seem revealing that the photographer has chosen a technique that could be described as old while working at the cutting edge of modern robotics. At a time when everything is becoming digital, when bodies themselves are dematerialized in medical imagery, 
Aguilera-Hellweg chose to highlight the materiality of his study. Yet he also uses digital tools and the Internet to publicize his work. Silver prints and digital technologies are thus presented as complementary, perhaps as is the human body and robotic object.

Figure 4: Max Aguilera-Hellweg, Geminoid F, humanoid series, 2017.

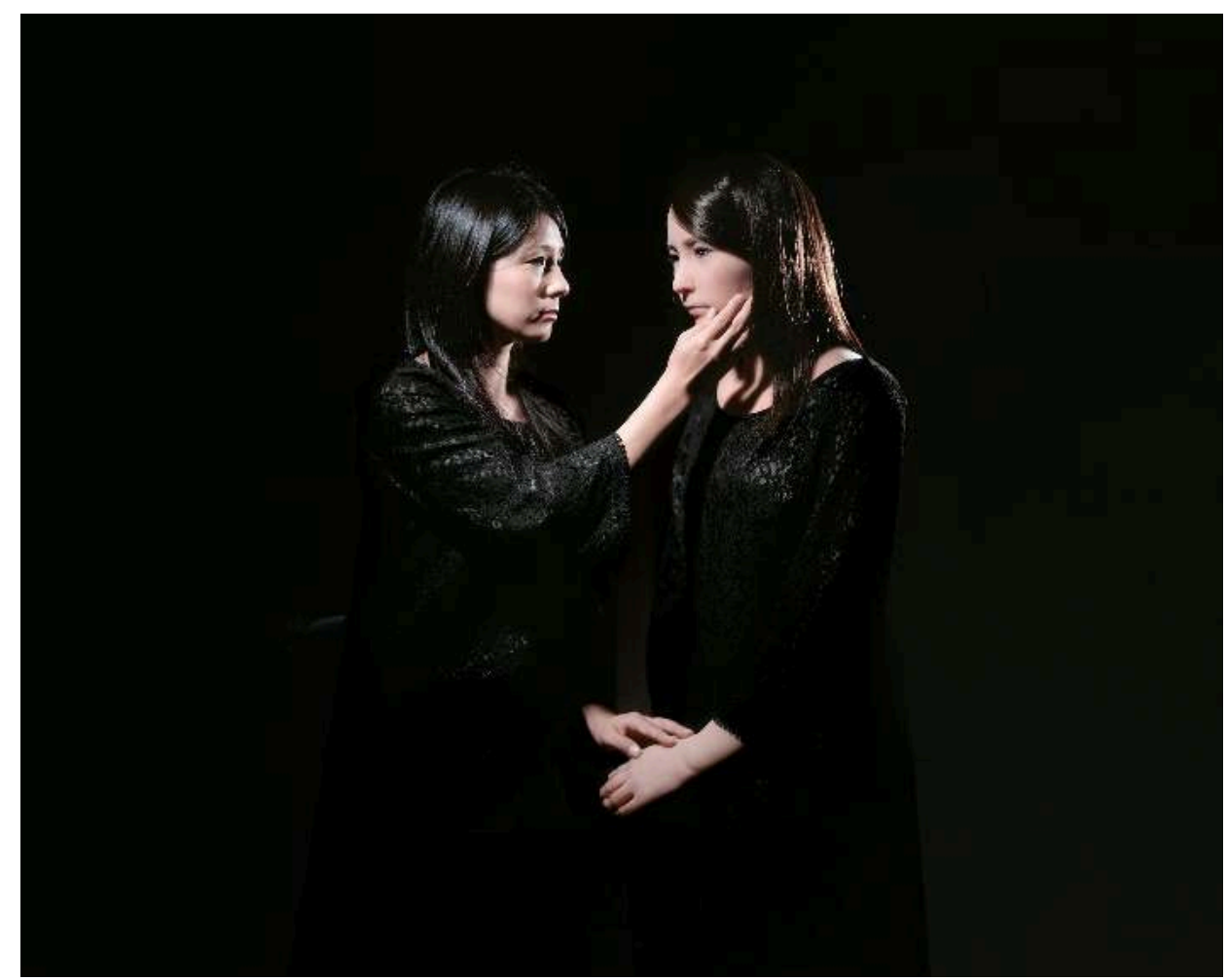

Source: https://aguilerahellweg.com/humanoid/yqvjpyv00xdcc2y1xugjsa49v6pvxu. All Rights Reserved.

20 In his work Geminoid F, Max Aguilera-Hellweg depicts one woman, acting as the original model, confronted with a hyper-realistic robot, her double, her twin, her clone. The photographer exploits the visual confusion reinforced by the hand gesture connoting empathy. Before shooting, the model explained to Aguilera-Hellweg that she was really attached to her simulacrum. This testimony was precisely transcribed in the photograph. Her gesture and affectionate gaze are out of step with the cold stance of the robot which stands emotionless. Lighting emphasizes the smooth appearance of the humanoid's skin, erasing all imperfections and volumes and thus reinforcing its artificiality; it also erases any features that may convey empathy on the part of the robot. Conversely, the play of shadows highlights the shape, the expressions and the defects of the human face. The artificial creature is presented as a troubling object to which one can attach oneself and for which one can experience feelings. Object and body function as a unit, so different and yet so similar.

\section{Conclusion}

21 Artists have always explored and questioned representations of life but the increased prevalence of anthropomorphic robots in our daily lives adds another perspective to that pursuit. We now co-exist both with the living and with anthropomorphic artefacts, 
in an age that opens up to the post-human as pointed out by Deitch in the catalogue of the Post-Human exhibition: "Artists will no longer be able to engage simply in redefining art. In the post-human era, they will no doubt also be involved in a new redefinition of life" (1993: 15).

Photographer and surgeon Max Aguilera-Hellweg fully participates in this redefinition of life. Building upon Masahiro Mori's theories of the uncanny valley, he shifted his focus from the surgical treatment of human bodies to anthropomorphic robotics. Placing man and machine on an equal footing through his sometimes-disturbing photographic treatment, he highlighted the illusion of life in artefacts and turned robots into more than objects, into eidolons. He chose to lay the emphasis not on deception, or on the artificiality of the artefact but on our empathy, on the feeling of being faced with something human (Victor-Pujebet 2014), revealing simultaneously the mechanical inner structure and the simulated identity of the robots. Conversely, his surgical photographs focus anonymous inert bodies, the cogs and wheels of their anatomy.

His work may be related to the evolution of our relation to objects since the second half of the $20^{\text {th }}$ century. Robots are not presented as inferior human replica but photographed as fully-fledged human beings while human beings are likened to smooth plastic figures. Roboticist Hiroshi Ishiguro's choice to undergo cosmetic surgery to remain identical to his robotic double is an extreme example of this shift between the body and the robot. Aguilera-Hellweg underlined the versatility of the process: "He created a robot in his own image and now he does everything to look like his robot." (Victor-Pujebet 2014: 35'38")

Man has made the machine in his image. She has limbs that act, lungs that breathe, a heart that beats, a nervous system where electricity runs. The phonograph is the image of his voice; the camera is the image of his eye. The machine is his "daughter born without a mother." Photography is one of the beautiful fruits of this union. The photographic proof is an element of this new trinity: man, the creator, thinking and wanting; the mother action machine; their product, the work. This machine was born without natural conception, without biological mother. (Haviland 1915: 4)

Max Aguilera-Hellweg's photographic work shows the aesthetic proximity of bodies and robots, the relations that bind them together and their interdependence. His photographs can be valued both as technological testimonies of our time, as fictional fantasies and as artistic illusions. In choosing to blur the frontiers between the two realm of the living and the artefact, his work echoes the jury's choice for the 2017 Taylor Wessing Photographic Prize, which was attributed to Maija Tammi's portrait of Erica, a robot created by Hiroshi Ishiguro, although the rules of the contest stipulate "all photographs must have been taken by the entrant from life and with a living sitter". Redefining life is very much on the agenda of the post-human era. 


\section{BIBLIOGRAPHY}

Aguilera-Hellweg, Max. Sacred Heart: An Atlas of the Body Seen Through Invasive Surgery. Boston: Bulfinch Press, 1997. French Transl. Le Cour sacré, Un atlas chirurgical du corps humain. Paris: Éditions de l'Éclat, 2006.

Aguilera-Hellweg, Max. Humanoid. New York: Blast Books, 2017.

Aguilera-Hellweg, Max. "Medecine and the Muse", Stanford Medecine, 2017. https:// stanmed.stanford.edu/2017winter/physician-photographer-max-aguilera-hellweg.html.

Alexandre, Elisabeth and Elena Dorfman. Des poupées et des hommes : enquête sur l'amour artificiel. Paris: La Musardine, 2005.

American Heritage. "Eidolon", Dictionary of the English Language. Boston: Houghton Mifflin Harcourt, 2016. https://ahdictionary.com/word/search.html?q=Eidolon.

Baldeck, Andrea. Bones Books \& Bell Jars. Photographs of the Mutter Museum Collection. Philadelphia: The College of Physicians of Philadelphia, 2012. http://alphaomegaalpha.org/ pharos/PDFs/2013-1-Books.pdf.

Borderie, Roger. La Femme surréaliste. Paris: Éditions Borderie, 1977.

Baudrillard, Jean. Simulacres et simulation. Paris: Éditions Galilée, 1981.

Bredekamp, Horst. Théorie de l'acte d'image. Paris: Éditions La Découverte, 2015.

Cassin, Barbara. Dictionnaire Le Robert. Paris: Éditions du Seuil, 2003.

Costello, Paul. "The Body Majestic: a conversation with physician-photographer Max AguileraHellweg” in Stanford Medicine, winter 2017. https://stanmed.stanford.edu/2017winter/physicianphotographer-max-aguilera-hellweg.html

Couchot, Edmond, Norbert Hillaire. L’Art numérique. Paris: Flammarion, 2005.

Deitch, Jeffrey. Post-human. Lausanne: FAE musée d'art contemporain, 1993.

Dufrêne, Thierry (ed). Persona : étrangement humain. Paris: Actes Sud Beaux-arts and Musée du Quai Branly, 2016.

Freud, Sigmund. Essais de psychanalyse appliquée. Paris: Éditions Gallimard, 1971.

Grimaud, Emmanuel. "Androïde cherche humain pour contact électrique." Gradhiva (15) 2012. DOI: $10.4000 /$ gradhiva.2328

Haviland, Paul B. “We Are Living in the Age of the Machine." 291. n 7-8, Sept.-Oct. 1915: 4.

Jentsch, Ernst. “L'inquiétante étrangeté.” Études psychothérapiques (17) 1998: 37-48.

Lalonde, Joanne. “Technologies du corps: Métamorphose et clonage.” Musée d'art contemporain de Montréal, ETC (55) 2001: 55-59.

Lascault, Gilbert. Figurées, défigurées: petit vocabulaire de la féminité représentée. Paris: Éditions du Félin, 2008.

Le Breton, David. Corps abîmés. Laval: Presse Universitaire Laval, 2013.

Mori, Masahiro. “La vallée de l'étrange.” Gradhiva, 2012. DOI: 10.4000/gradhiva.2311 
Ragazzini, Jessica. “Le mannequin photographié: l'exemple de Newton, Sherman, Rheims et Goldstein, 1975-2015.” Mémoire de master. Grenoble: Université de Grenoble-Alpes, 2017.

Russel, Ben. Robots: The 500-year quest to make machines human. London: Scala Arts \& Heritage Publishers Ltd, 2017.

Stoichita, Victor I. L'Effet Pygmalion: Pour une anthropologie historique des simulacres. Genève: Librairie Droz, 2008.

Vax, Louis. La Séduction de l'étrange. Paris: Presses universitaires de France, 1965.

Vigarello, Georges. La silhouette du XVIIIe siècle à nos jours : Naissance d'un défi. Paris: Seuil, 2012.

Wajcman, Judy. "Humanoid robots and the promise of an easier life." Robots: The 500-year quest to make machines human. B. Russel, ed. London: Scala Arts \& Heritage Publishers Ltd, 2017:103-104.

Whitehead, Anne, ed. "The Body beyond the anatomy lab: (Re)Addressing arts methodologies for the critical medical humanities." Edinburg Companion to the Critical Medical Humanities. Edinburgh: Edinburgh UP, 2016: 196.

Zapperi, Giovanna. "Pygmalion révisé." Rue Descartes (64) 2009: 110-116.

\section{Video}

Aguilera-Hellweg, Max. “Patient No. 17.” Youtube, 2011. https://www.youtube.com/watch? $\mathrm{v}=8 \mathrm{yS} 4 \mathrm{NQAtTmg}$.

Victor-Pujebet, Bruno, Marc Felix, Max Aguilera-Hellweg. Au cœur des robots! ARTE G.E.I.E, Illégitime Défense, 2015.

\section{NOTES}

1. Described by Hellweg on http://anatomyandart.tripod.com/id8.html and referenced by Anne Whitehead (2016).

\section{ABSTRACTS}

Anthropomorphic robotics have become increasingly familiar in our daily lives. Photographer and surgeon Max Aguilera-Hellweg moved from projects focusing on human bodies undergoing surgery to photographs of androids and their inner architecture. Why did the photographer choose to give up the human body to turn to its simulacrum? What does the robot have that the human body doesn't have? What is the point of photographing objects that resemble human beings? These are the questions that will guide our analysis of the work of Max Aguilera-Hellweg.

La robotique anthropomorphe prend de plus en plus de place dans notre quotidien. Le photographe et chirurgien Max Aguilera-Hellweg a photographié ces objets dont la forme ressemble étrangement à celle du corps humain. Pourquoi le photographe a-t-il choisi de renoncer au corps humain pour se tourner vers son simulacre? Que possède le robot que le corps 
humain ne possèderait pas ? Quel intérêt y-a-t-il à photographier des objets qui ressemblent à des êtres humains ? Voici les interrogations qui guideront notre analyse du travail de Max Aguilera-Hellweg.

\section{INDEX}

Mots-clés: robot, chirurgie, photographie, corps, étrangeté, Aguilera-Hellweg Max

Keywords: robot, surgery, photography, body, uncanny, Aguilera-Hellweg Max

\section{AUTHORS}

\section{JESSICA RAGAZZINI}

Jessica Ragazzini is a PhD Student in Art History (Université Paris Nanterre and Université du Québec en Outaouais). Her research focuses on the confusion and confrontation of the living with anthropomorphic simulacra, mainly in photography. She has presented her work in the international symposium 'Visages à Contraintes' (University of Saint Etienne, October 2017) at the University of Lyon (photography and science fiction). In addition to her doctoral training, she is a Master's student in philosophy at the University of Grenoble-Alpes. Contact: jessica.ragazzinicastello[at]gmail.com 